\title{
Pendampingan Petani Gaharu melalui Program Diversifikasi Produk Gaharu sebagai Usaha Peningkatan Pendapatan Petani Gaharu di Kabupaten Bangka Tengah
}

\author{
Henny Helmi, Eni Karsiningsih \\ ${ }^{1}$ Jurusan Biologi, ${ }^{2}$ Jurusan Agribisnis, Universitas Bangka Belitung \\ hennyhelmi24@gmail.com
}

\begin{abstract}
Agarwood is a kind of fragrant wood which used as raw material in parfume industry, cosmetics, and medicine. Agarwood was formed by infected of fungy to several species from plant of genus Acquillaria. Farmer groups (Gapoktan Alam Jaya Lestari and Poktan Air Pasir Maju) are partners involved in this program. Both of these farmers groups had problems in availability of inoculant and the expensive price of inoculant. Besides, group farmers havenot known well of inoculatuion techniques. This program was conducted by Participation Action Researh (PAR). Fungi inoculant propagation were practiced in a simple way using potato and sugar as raw materials. Both of partners were very passionate on inoculant training activities, even farmers wanted to try to make inoculants of various materials which avalaible at their sourrounding. On the inoculation techniques, spiral method using both liquid and powders inoculants were injected to gaharu plant. Farmers were trained drafting technique as alternative product of agarwood such as tasbeeh. In addition, farmers trained to calculate a profit of agarwood product. To be independent farmer group, Poktan Air Pasir Maju still needs to be trained further because of their strong willingness to develop agarwood but still lacking skill.
\end{abstract}

Keyword: Agarwood, inoculant, independent farmer groups, inoculation

\section{Pendahuluan}

Gaharu merupakan sejenis kayu dengan warna yang khas berupa gumpalan atau padatan biasanya dimanfaatkan sebagai bahan dasar pada berbagai industri seperti parfum, dupa, kosmetik, dan obat-obatan. Meningkatnya perdagangan gaharu sejak tiga dasawarsa terakhir ini telah menimbulkan kelangkaan produksi gubal gaharu dari alam. Besarnya permintaan pasar, harga jual yang tinggi, dan pola pemanenan yang berlebihan serta perdagangan yang masih mengandalkan pada alam tersebut, menyebabkan jenis-jenis tertentu misalnya Aquilaria khususnya A.malaccensis saat ini sudah tergolong langka, dan masuk dalam lampiran Convention on International Trade on Endangered Species of Flora and Fauna. ${ }^{1}$

Gaharu tidak terbentuk pada pohon sehat tetapi pada pohon sakit, terbentuknya gubal gaharu berkaitan dengan gejala patologis yang diawali dengan infeksi cendawan. Beberapa cendawan seperti Acremonium dan Fusarium telah dibuktikan mampu menginduksi pembentukan

\footnotetext{
${ }^{1}$ Barden A, Anak NA, Mulliken T, Song M. Heart of the Matter: Agarwood Use and Trade and CITIES Implementation for Aquilaria malaccensis. Cambridge: Traffic Int, 2000
}

Volume 2, Number 1, Mei 2018|37

Pendampingan Petani Gaharu melalui Program Diversifikasi Produk Gaharu sebagai Usaha Peningkatan Pendapatan Petani Gaharu di Kabupaten Bangka Tengah

Henny Helmi, Eni Karsiningsih 
senyawa gaharu2. Cendawan ini dijadikan inokulan. Inokulan ini kemudian disuntikkan atau diinokulasikan ke batang pohon gaharu. Pohon gaharu akan menghasilkan damar/resin yang wangi sebagai bentuk pertahanan pohon gaharu terhadap infeksi cendawan. ${ }^{3}$

Prospek gaharu menjadi komoditi andalan semakin terbuka dengan ditemukannya teknologi rekayasa produksi gaharu. Melalui teknologi inokulasi ini maka produksi gaharu dapat direncanakan dan dipercepat melalui induksi jamur pembentuk gaharu pada pohon penghasil gaharu. Peningkatan produksi gaharu dimaksud (yang kegiatannya terdiri dari kegiatan di bagian hulu sampai hilir) selanjutnya akan berdampak pada peningkatan penerimaan oleh masyarakat petani, pengusaha gaharu, dan penerimaan pendapatan asli daerah serta devisa Negara. ${ }^{4}$

Salah satu Kabupaten yang fokus terhadap pengembangan gaharu adalah Kabupaten Bangka Tengah. Kabupaten ini memiliki 67 kelompok tani (Poktan) gaharu, namun hanya beberapa Poktan yang aktif. Kurangnya pembinaan, pendampingan, mahalnya harga inokulan menyebabkan tidak aktifnya Poktan gaharu. Poktan gaharu yang aktif antara lain Poktan Gaharu Harapan I, II, dan III Desa Lubuk Pabrik tergabung dalam Gabungan Poktan (Gapoktan) Alam Jaya Lestari dan Poktan Air Pasir Maju Desa Lampur. Masalah yang dihadapi ditingkat Poktan (mitra) adalah ketergantungan inokulan yang dibeli atau dikirim dari luar Bangka. Mahalnya harga inokulan (Rp. 500.000/liter), menyebabkan petani lebih menyenangi proses pembentukan gaharu secara alami. Kondisi ini dapat diatasi dengan cara memperbanyak sendiri inokulan cendawan. Teknik perbanyakan ini dapat dilakukan secara sederhana dengan menggunakan bahan yang sering ditemukan sehari-hari seperti kentang dengan menggunakan konsep sterilisasi secara sederhana.

Selain permasalahan inokulan, keberhasilan pembentukan gaharu juga ditentukan oleh teknik inokulasi. Teknik inokulasi yang sering dilakukan berupa teknik spiral dengan melobangi kayu dengan kedalaman tertentu dan rumus tertentu. Sayangnya, anggota Poktan gaharu belum mampu melakukan teknik inokulasi ke batang tanaman secara tepat. Akibatnya belum maksimalnya pembentukan wangi atau menyebabkan tanaman menjadi mati dan tumbang. Permasalahan inokulan dan teknik inokulasi ke batang merupakan faktor pendukung ketergantungan petani gaharu pada proses inokulasi secara alami. Permasalahan lain yang dihadapi oleh petani gaharu yaitu belum mengetahui produk lain yang bisa dijual selain gubal gaharu. Tahapan ini merupakan

2 Putri A, Rahayu G, Juliarni. Induksi Pembentukan Wangi dan Senyawa Terpenoid pada Pohon Gaharu denganAcremonium sp. dan Metil Jasmonat. (Jurnal Pertanian dan Lingkungan) 2007,2 (1):23-28

${ }^{3}$ Michiho,I. 2005. Induction of sesquiterpenoid Production by Methyl Jasmonate in Aquilaria sinensis Cell Suspension Culture. (Essential oil Research). http://www.findarticle.com (20 April 2014)

${ }^{4}$ Panjaitan S, Eko HK, Tri W, dan Edy S. Prospek dan Teknik Budidaya Tumbuhan gaharu (Aquilaria malaccensis) di Kalimantan. Banjar Baru: Balai Penelitian Kehutanan BPDAS Barito, 2009

Volume 2, Number 1, Mei 2018|38

Pendampingan Petani Gaharu melalui Program Diversifikasi Produk Gaharu sebagai Usaha Peningkatan Pendapatan Petani Gaharu di Kabupaten Bangka Tengah 
proses yang bisa memberikan nilai tambah bagi produk gaharu, dengan mengolah pohon gaharu yang telah dipanen. Keterbatasan pengetahuan dan keterampilan petani terhadap produk selain gubal kayu menyebabkan petani hanya menjual gubal saja. Padahal disamping gubal dapat juga dihasilkan juga produk lain yang dapat meningkatkan pendapatan para petani.

\section{Metode}

Pelaksanaan kegiatan pengabdian masyarakat ini dilakukan melalui penekanan pada pemberdayaan masyarakat (dalam hal ini kelompok tani) sebagai mitra atau Participatory Action Research (PAR). Hal ini bertujuan agar masyarakat dapat dilibatkan secara langsung dan berperan aktif dalam menyerap teknologi dalam pengolahan gaharu ini. Program ini juga melibatkan tenaga lapangan dan Kepala Bidang Teknologi dan Pengembangan dari Dinas Perkebunan dan Kehutanan Bangka Tengah sehingga diharapkan setelah kegiatan ini selesai masih ada pembinaan dan pendampingan dari Dinas terkait. Kegiatan ini berlangsung di Desa Lampur, Kecamatan Sungaiselan, dan Desa Lubuk Pabrik, Kecamatan Lubuk. Kedua desa ini termasuk dalam wilayah Kabupaten Bangka Tengah provinsi Kepulauan Bangka Belitung. Proses pendampingan berlangsung selama 7 bulan mulai dari bulan April sampai November 2016.

Program pengabdian pada masyarakat ini menggunakan beberapa metode disesuaikan dengan luaran yang diharapkan. Beberapa metode tersebut merupakan satu kesatuan yang ditujukan pada keberhasilan iptek yang akan diimplementasikan pada kelompok masyarakat sasaran. Metode tersebut terdiri dari sosialisasi pentingnya konservasi gaharu, transfer iptek mengenai teknologi perbanyakan inokulan gaharu secara sederhana menggunakan media kentang dan transfer teknik inokulasi dengan menggunakan inokulan cair dan padat, transfer iptek mengenai pembuatan tasbih sebagai usaha diversifikasi produk selain gubal gaharu dan pelatihan pembuatan pembukuan sederhana.

Sosialisasi konservasi gaharu dilakukan untuk memberikan kesadaran masyarakat agar tidak mengambil gaharu dari pohon alami karena beberapa pohon gaharu alami seperti A.mallacensis tergolong langka. Sosialisasi juga bertujuan untuk menyadarkan masyarakat agar melakukan budidaya gaharu dan tidak tergantung dari pohon gaharu alam. Sosialisasi didampingi oleh Dinas Kehutanan dan Perkebunan Bangka Tengah sehingga kegiatan pengabdian ini dapat berkelanjutan dengan sinergisme program dari Pemerintahan Daerah (PEMDA) Bangka Tengah. Program budidaya gaharu telah digalakkan oleh PEMDA Bangka Tengah sejak sebelum 2010 sehingga menjadikan kabuapaten ini sebagai salah satu sentra gaharu nasional di tahun 2010. Pihak PEMDA

Volume 2, Number 1, Mei 2018|39

Pendampingan Petani Gaharu melalui Program Diversifikasi Produk Gaharu sebagai Usaha Peningkatan Pendapatan Petani Gaharu di Kabupaten Bangka Tengah 
juga dapat membuat rantai penjualan gaharu sehingga dapat memastikan harga jual gaharu.

Transfer teknologi perbanyakan inokulan gaharu secara sederhana dilakukan dengan beberapa tahapan yaitu pembuatan media, teknik sterilisasi, teknik penuangan media dan teknik transfer cendawan ke media. Teknologi perbanyakan inokulan ini menggunakan bahan-bahan dan alat-alat yang tersedia dimasyarakat dan dilakukan dengan metode yang sederhana sehingga diharapkan masyarakat dapat menerima ipteks yang ditawarkan. Media yang digunakan seperti kentang, gula pasir, agar, yang tersedia di masyarakat. Media ini merupakan nutrisi untuk pertumbuhan cendawan sebagai inokulan. Teknik sterilisasi juga menggunakan kompor, kukusan serta botol kaca sebagai wadah media. Pengerjaan transfer inokulan (cendawan/fungi) dari indukan untuk perbanyakan dibuat dari bahan triplek dan kaca serta alat transfer berupa kawat atau pisau kecil. Teknik inokulasi inokulan gaharu ke batang gaharu dilakukan dengan metode spiral dengan menggunakan media cair dan padat. Pembuatan tasbih/gelang gaharu dilakukan dengan mengunakan mesin gerinda (bor duduk). Berikutnya dilakukan proses penghalusan butiran tasbih dengan menggunakan amplas. Tahap akhir dari kegiatan pengabdian masyarakat ini dilakukan perhitungan keuntungan terhadap produk olahan gaharu non-kayu gaharu dan pembukuan sederhana. Analisis keuntungan ini berguna untuk mengetahui besarnya keuntungan yang akan diperoleh petani dari produk olahan selain kayu. Secara matematis dapat dirumuskan sebagai berikut : $\pi=\mathrm{TR}-\mathrm{TC}$ dimana $\pi=$ Keuntungan, $\mathrm{TR}=$ Total Penerimaan, $\mathrm{TC}=$ Total Biaya.

Diharapkan setelah kegiatan ini dapat terbentuk kelompok tani mandiri yang tidak menggantungkan inokulan dari luar Bangka atau membeli dari orang lain, dan dapat menginokulasi sendiri inokulan yang dibuat ke batang gaharu. Budidaya gaharu dapat mengatasi ketergantungan petani terhadap alam sehingga hasil panen dapat diprediksi dan tidak tergantung dari ketersediaan pohon gaharu di alam. Kelemahan inokulasi alami tergantung dari alam sehingga tidak dapat diprediksi kapan waktu panen dan tingkat wangi dari gaharu yang dihasilkan karena tergantung dari cendawan alamai apa yang menginfeksi batang gaharu tersebut. Adapun gambaran pengabdian ini untuk menyelesaikan masalah yang dihadapi oleh mitra dapat dilihat pada gambar 1.

Volume 2, Number 1, Mei 2018| 40

Pendampingan Petani Gaharu melalui Program Diversifikasi Produk Gaharu sebagai Usaha Peningkatan Pendapatan Petani Gaharu di Kabupaten Bangka Tengah

Henny Helmi, Eni Karsiningsih 


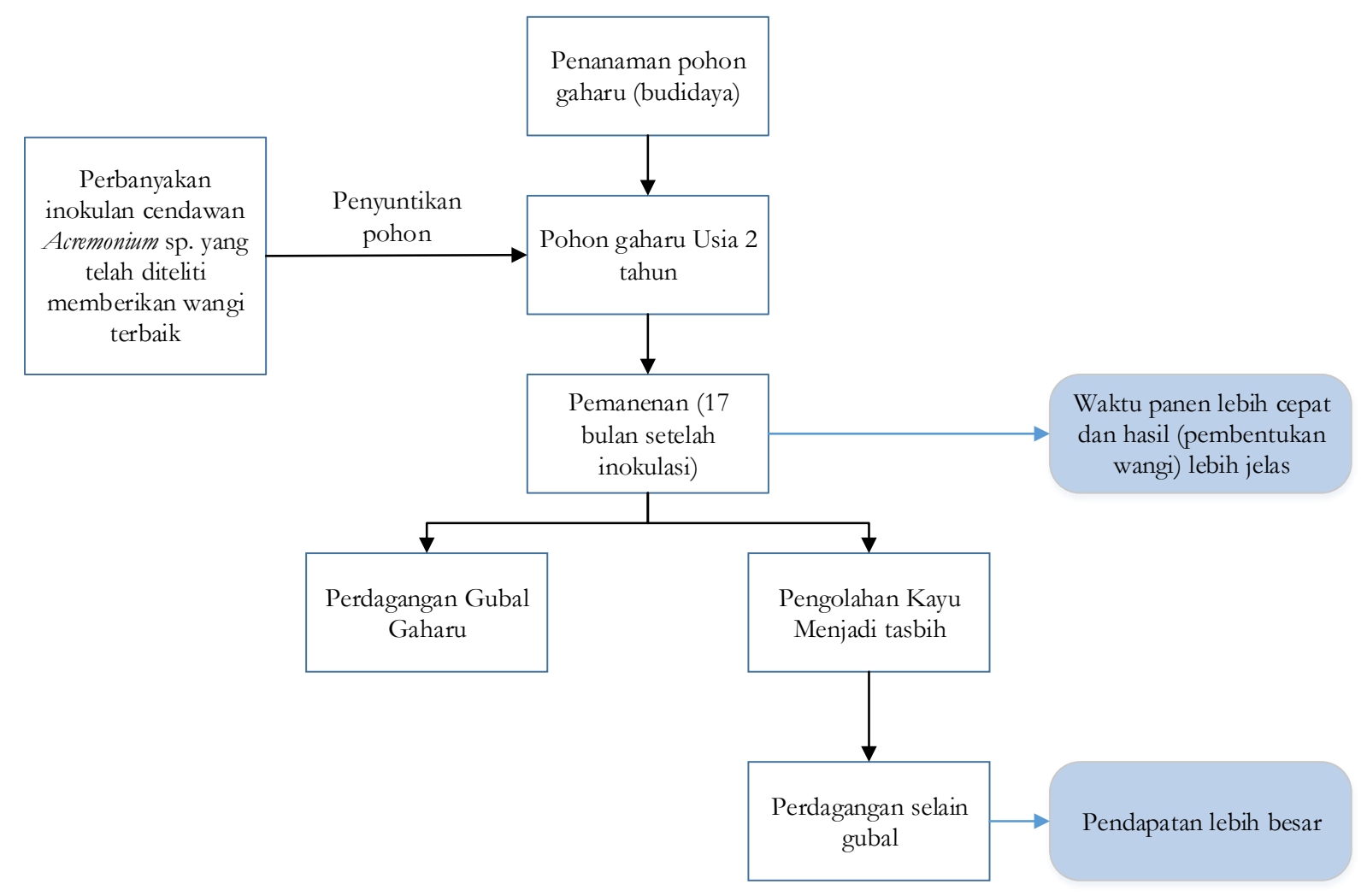

Gambar 1. Bagan solusi masalah yang ditawarkan pada program pengabdian

\section{Hasil dan Diskusi}

Pada kegiatan pengabdian masyarakat ini ada 5 kegiatan yang dilakukan yaitu sosialisasi konservasi tumbuhan gaharu, pelatihan dan pendampingan cara perbanyakan inokulan, pelatihan dan pendampingan teknik inokulasi, pelatihan produk lain selain kayu gaharu, pelatihan analisis keuntungan dan pembukuan sederhana. Kelima kegiatan ini dilakukan di Dusun Air Pasir Maju Desa Lampur dan Desa Lubuk Pabrik.

\section{Sosialisasi Konservasi Tumbuhan Gaharu}

Adapun luaran yang diharapkan dari kegiatan ini yaitu: masyarakat mendapatkan pengetahuan yang sempurna mengenai perlunya konservasi tumbuhan gaharu sehingga timbul keinginan masyarakat membudidayakan tanaman gaharu guna memperbaiki taraf hidup petani serta menimbulkan kesadaran kepada masyarakat untuk melestarikan tumbuhan gaharu alami. Pada kegiatan ini tim pengabdian mengundang Kepala Bidang Teknologi dan Pengembangan dari Dinas Perkebunan dan Kehutanan Bangka Tengah sebagai narasumber. Pada kegiatan ini selain dilakukan 
sosialisasi konservasi gaharu, dijelaskan juga program dan kegiatan-kegiatan yang akan dilakukan dalam kegiatan pengabdian masyarakat ini. Pada prinsipnya, kelompok tani baik di desa Lampur maupun Lubuk Pabrik sangat mendukung kegiatan pengabdian ini, terutama Poktan Air Pasir Maju karena mereka belum banyak menerima bantuan dan pelatihan baik dari Badan Litbang Kehutanan maupun dari dinas Perkebunan dan Kehutanan Kabupaten Bangka Tengah.

Pada kegiatan ini dibahas mengenai pengaturan perdagangan gaharu oleh CITES dan dijelaskan alasan mengapa pohon gaharu masuk dalam kategori Appendix II oleh Convention on International Trade on Endangered Species of Flora and Fauna (Appendix II CITES). Gaharu alami, perdagangannya diatur oleh ASGARIN (Asosiasi Pedagang Gaharu Indonesia). Namun, gaharu budidaya pengaturan perdagangannya diatur oleh Peraturan No. 8 tahun 1999 tentang Pemanfaatan Jenis Tumbuhan dan Satwa Liar dan Surat Keputusan Menetri Kehutanan No.447 tahun 2003 sehingga untuk perdagangan gaharu harus memiliki izin sebagai pengedar gaharu. Masuknya Gaharu alam dalam Appendix II CITES sehingga petani diharapkan dapat membudiaya gaharu, dengan cara menanam bibit gaharu terutama A.mallacensis dan kemudian melakukan penyuntikan sendiri karena gaharu akan terbentuk sebagai hasil gangguan dan proses infeksi yang terjadi baik secara alami atau buatan pada pohon yang dibudidayakan oleh masyarakat.

Permasalahan yang paling banyak ditanyakan oleh masyarakat yang hadir yaitu kepastian harga dan regulasi yang mengatur perdagangan gaharu. Saran yang diajukan oleh masyarakat adalah adanya asosiasi yang melindungi dan menjaga pasar gaharu budidaya, jika gaharu alami ada asosiasinya ASGARIN, maka perlu dibentuk asosiasi untuk gaharu budidaya. Pihak Dinas Perkebunan dan Kehutanan Bangka Tengah berjanji akan membantu petani mengurusi perdagangan dan merekomendasikan pengumpul yang membeli gaharu budidaya dari petani sehingga petani menjual gaharu kepada pengumupul yang akan mengimpor ke luar negeri.
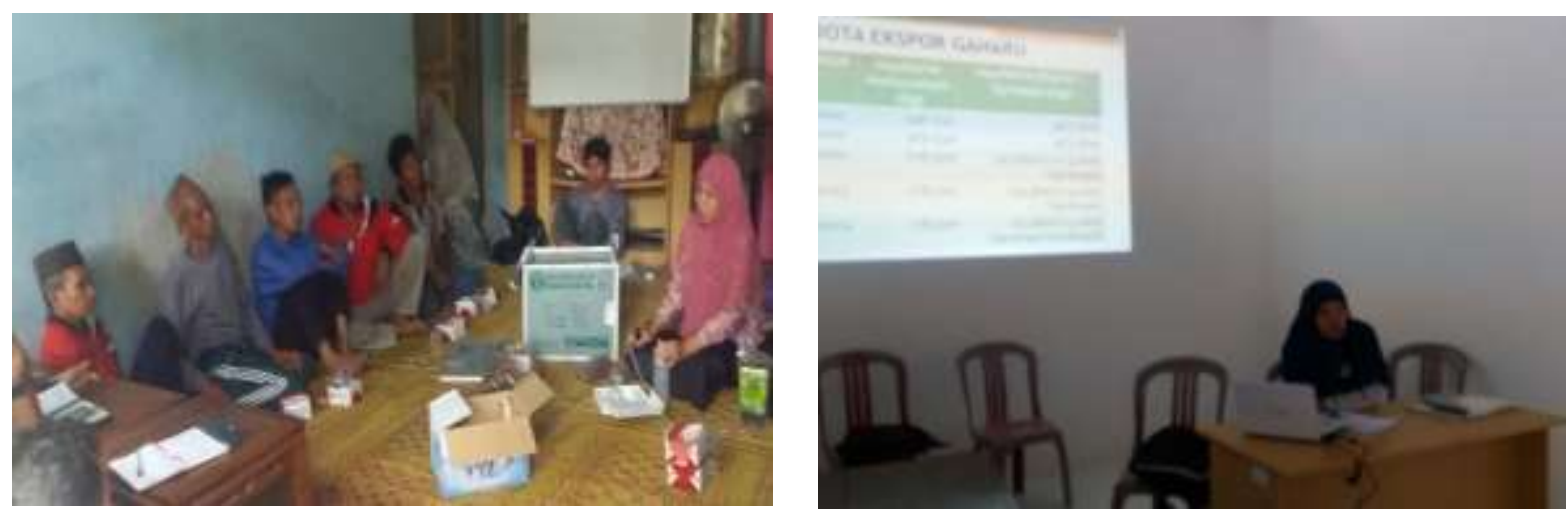

Gambar 2. Sosialisasi konservasi gaharu: Poktan Air Pasir Maju (kiri), Gapoktan Alam Jaya Lestari (kanan)

Volume 2, Number 1, Mei 2018| 42

Pendampingan Petani Gaharu melalui Program Diversifikasi Produk Gaharu sebagai Usaha Peningkatan Pendapatan Petani Gaharu di Kabupaten Bangka Tengah

Henny Helmi, Eni Karsiningsih 


\section{Pelatihan dan pendampingan cara perbanyakan dan pembuatan inokulan}

Target luaran kegiatan ini yaitu mampu meningkatkan pengetahuan masyarakat khususnya petani gaharu dan sekaligus keterampilan cara memperbanyak inokulan sehingga diharapkan masyarakat mampu memproduksi inokulan sendiri dan pada akhirnya dapat menurunkan tingkat ketergantungan inokulan dari luar Provinsi Bangka Belitung. Di desa Lampur (Poktan Air Pasir Maju) tidak hanya anggota tani yang hadir namun ibu-ibu (istri anggota kelompok yani juga ikut hadir). Pada kegiatan ini masyarakat dilatih membuat inokulan sederhana dari bahan baku kentang, gula pasir, dan antibiotik. Bahan yang harus disiapkan yaitu: kentang (200 gram), gula pasir 20 gram (1 sendok makan penuh), agar-agar (merk Swallow 14 gram/2 bungkus), dan antibiotik (kloramfenikol atau amoxycilin), kapas dan air bersih sebanyak 1 Liter. Sedangkan peralatan yang digunakan adalah botol kaca bekas (botol saus/kecap/teh), kompor, kukusan/dandang, baskom, pisau, talenan, dan gas elpiji.

Media kaldu kentang dibuat dengan cara: Pertama kentang yang telah ditimbang dikupas, dipotong dadu sekitar 1x1 cm kemudian dicuci bersih. Kentang kemudian direbus dengan 1L air bersih sampai mendidih hingga kentang menjadi empuk, kemudian disaring menggunakan saringan kelapa. Hasil saringan ditambahkan dengan gula pasir dan air hingga volume menjadi 1L. Media kaldu kentang ini kemudian diletakkan ke dalam wadah yang tahan panas (botol kaca) seperti botol saos, botol kecap, botol sirup dan teh botol. Media ini kemudian disterilisasi dengan menggunakan panci kukusan sederhana dan menggunakan kompor sebagai pemanas. Botol yang berisi media kaldu ditutup dengan sumbat kapas kemudian diikat dengan plastik tahan panas, kemudian disusun dalam panci kukusan. Proses sterilisasi dihitung 25 menit setelah air dalam kukusan mendidih.

Sebelum dilakukan inokulasi cendawan pada media, dibuat terlebih dahulu enkas yang fungsinya sama dengan Laminar Air Flow. Alat ini berguna untuk menjaga agar udara sekitar pada saat inokulasi steril dari mikroba kontaminasi sehingga cendawan yang diinginkan tumbuh bukan cendawan kontaminan/pengganggu. Enkas dibuat seperti kotak dengan bagian depan dilapisi kaca dan ada lobang/wadah tempat memasukkan tangan dan peralatan yang digunakan untuk pembuatan inokulan Sebelum pembuatan inokulan, enkas disterilisasi dengan menyemprotkan alkohol pada dinding enkas, kemudian dilap dengan menggunakan tissue kertas. Setelah itu lampu UV (ultraviolet) dinyalakan selama 20 menit. Selama kerja didalam enkas dibantu dengan bunsen/kompor kecil (api dan spritus), untuk mentransfer cendawan digunakan kawat/pisau curter yang sebelumnya dibakar terlebih dahulu diatas api sampai pijar (berwarna merah).

Volume 2, Number 1, Mei 2018| 43

Pendampingan Petani Gaharu melalui Program Diversifikasi Produk Gaharu sebagai Usaha Peningkatan Pendapatan Petani Gaharu di Kabupaten Bangka Tengah 
Sebelum pembuatan inokulan, enkas disterilisasi dengan menyemprotkan alkohol pada dinding enkas, kemudian dilap dengan menggunakn tissue kertas. Selama kerja didalam enkas dibantu dengan Bunsen/kompor kecil (api dan spritus), untuk mentransfer cendawan digunakan kawat/pisau curter/sendok yang sebelumnya dibakar terlebih dahulu diatas api sampai pijar (berwarna merah).

Tahapan berikutnya adalah tahap inokulasi cendawan Acremonium sp. Cendawan isolat murni Acremonium sp. berasal dari Dinas Perkebunan dan Kehutanan Bangka Tengah. Cendawan dimasukkan ke dalam media kaldu kentang yang telah steril dan dingin. Pertama-tama, tangan dicuci terlebih dahulu dengan sabun kemudian disemprot alkohol kemudian masukkan semua peralatan yang digunakan ke dalam enkas, kemudian bakar pisau curter/kawat dengan api (Bunsen) biarkan dingin, lalu buka cawan stok inokulum, bakar mulut tabung reaksi untuk menghindari kontaminasi, ambil dengan menggunakan kawat lalu pindahkan ke medium kaldu kentang. Tutup botol dengan kapas dan koran lalu inkubasi didalam lemari untuk menggantikan inkubator. Inkubasi selama 3-4 hari sampai terbentuk gumpalan putih pada media. Inokulan ini bisa diperbanyak lagi dengan cara yang hampir sama, pertama enkas disterilkan lalu masukkan semua bahan dalam enkas. Buka botol inokulan (jadikan sebagai stok) dan juga botol yang berisi media kaldu yang baru, bakar mulut botol, setelah itu tuangkan inokulan yang telah tumbuh ke botol yang baru, sebayak 1/10 dari jumlah media yang ada pada botol yang baru. Inkubasi selama 3-5 hari sampai terbentuk gumpalan berwarna putih. Pada pembuatan media padat dilakukan dengan cara, buka tutup cawan petri, kemudian potong cendawan berikut agarnya dengan menggunakan pisau cutter yang telah dibakar sampai pijar dan didinginkan kemudian pindahkan ke media kentang padat yang telah dimiringkan dan diinkubasi di lemari selama 3-5 hari.

Pada kegiatan ini juga dijelaskan fungsi masing-masing bahan dan proses yang dilakukan. Kentang berfungsi sebagai sumber karbohidrat begitu juga dengan gula. Gula berperan sebagai sumber karbohoidrat sederhana juga berperan menjaga tekanan osmosis sel. Air berfungsi sebgai pelarut, sedangkan antibiotik berperan untuk mencegah pertumbuhan bakteri. Proses sterilisiasi dengan menggunakan kukusan (sterilisasi basah dan uap) dilakukan agar tidak terjadi kontaminasi sehingga yang tumbuh hanya cendawan yang diharapkan.

Masyarakat tampak antusias pada kegiatan pelatihan ini, dan terjadi diskusi dengan masyarakat beberapa pertanyaan yang diajukan oleh masyarakat antara lain: Dimanakah bisa mendapatkan antibiotik dan harganya berapa, dan takarannya bagaimana? Pertanyaan tersebut dijawab dengan: antibiotik bisa dibeli di toko obat atau di puskesmas. Harga untuk amoxicillin

Volume 2, Number 1, Mei 2018| 44 Pendampingan Petani Gaharu melalui Program Diversifikasi Produk Gaharu sebagai Usaha Peningkatan Pendapatan Petani Gaharu di Kabupaten Bangka Tengah 
Rp.1.000,00 per 10 butir, dan kloramfenikol Rp.3.000,00 per 10 butir. Takarannya lihat pada dosis antibiotik ada yang $250 \mathrm{mg}$ dan $500 \mathrm{mg}$. Jika $250 \mathrm{mg}$ masukkan 2 kapsul, tapi jika $500 \mathrm{mg}$ cukup 1 kapsul. Kemudian masyarakat menanyakan bahan alternatif selain kentang. Pertumbuhan cendawan sebagai inokulan secara buatan pada prinsipnya menyediakan sumber karbohidrat untuk pertumbuhan cendawan. Sumber karbohidrat tersebut yang biasa digunakan adalah kentang, namun bisa juga menggunakan jagung atau karbohidrat lainnya. Pertanyaan terakhir mengenai takaran gula 20 gram jika tidak ada timbangan bagaimana? Bolehkah gula pasir dimasukkan banyak lebih dari 20 gram? Takaran 20 gram dikira-kira sekitar 1 sendok makan penuh, jika berlebihan akan menganggu tekanan osmosis sel cendawan/jamur.

Hasil monitoring untuk inokulan dilakukan seminggu setelah pembuatan inokulan bertepatan dengan pelatihan diversifikasi dan analisi keuntungan. Hasil pembuatan inokulan di desa Lampur dari 20 botol hanya 1 botol yang tidak kontaminasi sedangkan di desa Lubuk dari 25 botol tidak ada yang berhasil semuanya kontaminasi. Pertumbuhan cendawan inokulan harus dihindari kontaminasi. Kontaminasi dapat menyebabkan tumbuhnya cendawan bukan target (cendawan Acremonium sebagai inokulan). Kontaminan dapat menyebabkan gagalnya proses pembentukan gubal gaharu jika diinokulasi ke batang gaharu. Kondisi pelatihan yang banyak orang, dan dikerjakan oleh banyak orang merupakan salah satu penyebab kontaminasi. Teknik sterilisasi sederhana yaitu dengan menggunakan kukusan yang biasa terdapat di rumah. Waktu sterilisasi yang terlalu singkat karena waktu pelatihan yang singkat (sterilisasi kaldu kentang sebagai media pertumbuhan cendawan pada air mendidih dalam kukusan selama 20-25 menit tidak cukup steril) sehingga disarankan pengukusan media inokulan waktunya diperpanjang hingga 60 menit dan harus dikerjakan ditempat yang tertutup,tidak berdebu, tidak banyak orang.

Pada saat pemantauan perbanyakan inokulan diajarkan juga teknik killing untuk membunuh dan membersihkan kontaminan dari botol dengan teknik perebusan. Hal ini diajarkan supaya petani atau masayarakat tidak terkontaminasi oleh cendawan karena dikhawatirkan ada yang membahayakan kesehatan. Jadi sebelum botol dicuci dan dibersihkan, botol bekas dan botol yang telah terkontaminasi direbus terlebih dahulu. Botol yang telah dicuci dikeringkan dan sebelum digunakan untuk dimasukkan media maka dikukus terlebih dahulu.

Volume 2, Number 1, Mei 2018| 45

Pendampingan Petani Gaharu melalui Program Diversifikasi Produk Gaharu sebagai Usaha Peningkatan Pendapatan Petani Gaharu di Kabupaten Bangka Tengah 
ENGAGEMENT

Jurnal Pengabdian Kepada Masyarakat

ISSN: 2579-8375 (Print)

ISSN: 2579-8391 (Online)
This work is licensed under a Creative Commons Attribution-ShareAlike 4.0 International License. CC BY SA a

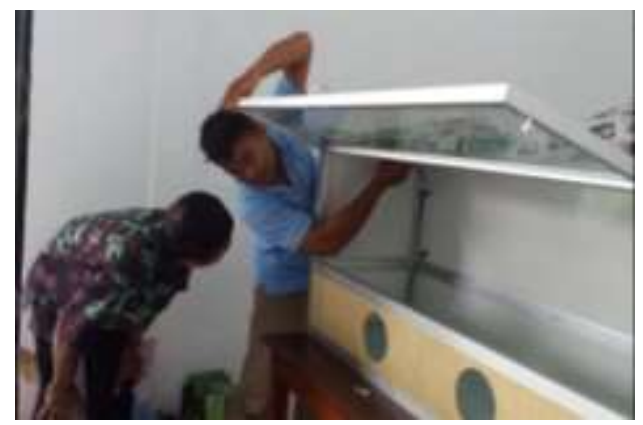

c

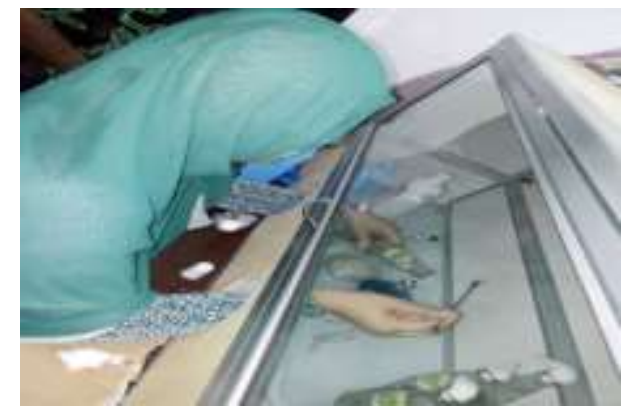

e

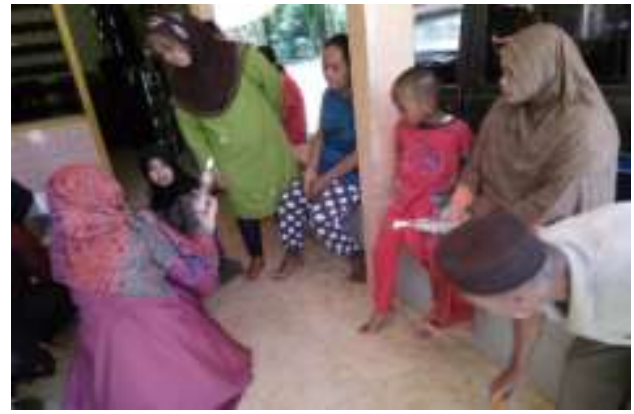

$\mathrm{b}$

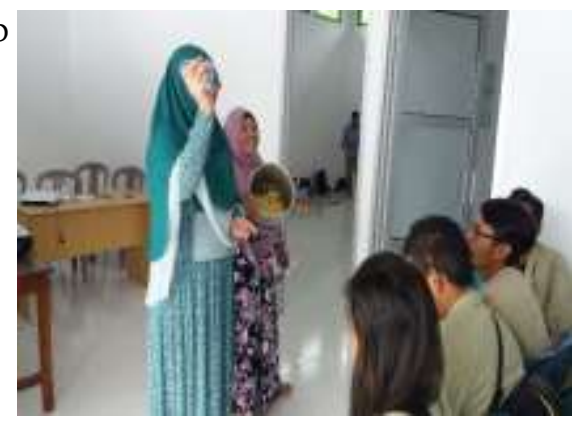

$\mathrm{d}$
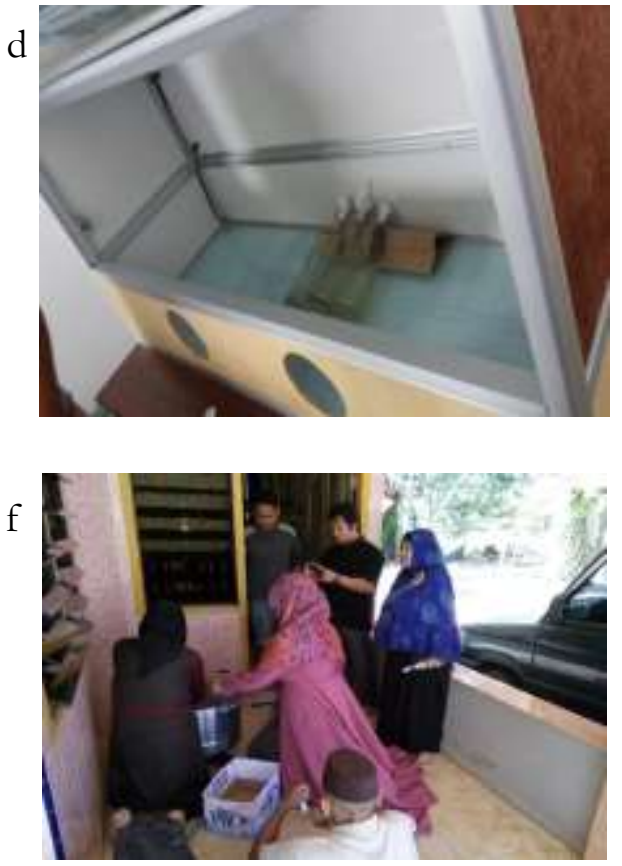

Gambar.3. Pelatihan pembuatan inokulan (a) penjelasan bagian-bagian enkas dan fungsinya, (b) penjelasan pembuatan media, (c) penjelasan teknik transfer cendawan dan perbanyakan inokulan, (d) pembuatan media agar miring, (e) penjelasan ciri media yang tidak terkontaminasi, (f) killing media yang terkontaminasi.

\section{Pelatihan dan pendampingan cara teknik inokulasi}

Target kegiatan ini yaitu petani gaharu mampu meningkatkan pengetahuan dan sekaligus keterampilan teknik inokulasi ke batang pohon gaharu. Kegiatan ini dibantu oleh tenaga lapangan Dinas Kehutanan dan Perkebunan Bangka Tengah mengingat banyaknya masyarakat yang harus dilatih dan batang yang disuntik. Teknik yang digunakan yaitu teknik spiral dengan proses pengeboran batang gaharu dengan jarak dan kedalaman tertentu tergantung dari ukuran diameter batang gaharu. Dengan menggunakan bor listrik dibuat lobang, lalu disuntikkan inokulan gaharu.

Volume 2, Number 1, Mei 2018| 46 Pendampingan Petani Gaharu melalui Program Diversifikasi Produk Gaharu sebagai Usaha Peningkatan Pendapatan Petani Gaharu di Kabupaten Bangka Tengah 
Proses ini merupakan proses pelukaan dan pemasukkan cendawan buatan sebagai usaha untuk mempercepat pembentukan damar/resin wangi yang merupakan respon tanaman untuk memproteksi diri dari gangguan. Teknik ini diharapkan dapat mempercepat pembentukan gubal gaharu/ damar wangi. Selain itu dengan menggunakan teknik inokulasi buatan dapat direncanakan waktu panen. Biasanya 17 bulan setelah inokulasi gubal gaharu sudah bisa dipanen.

Pada tahapan ini dijelaskan mekanisme pembentukan gubal gaharu yang merupakan respon tanaman terhadap adanya cendawan yang masuk ke dalam jaringan tanaman yang terluka. Ada 17 genus cendawan yang telah berhasil diisolasi dari gubal agahru alami, namun yang sering digunakan adalah Fusarium dan Acremonium. Alat dan bahan yang diperlukan yaitu: Bor kayu dengan ukuran minimal $10 \mathrm{~mm}$, sesuai dengan diameter batang semakin besar diameternya maka ukuran bor semakin besar, ukuran bor yang biasa digunakan berukuran $13 \mathrm{~mm}$, genset kapasitas 450 watt atau 900 watt dan alat bor listrik. Spidol permanent sebagai penanda titik bor. Alat ukur meteran untuk mengukur keliling batang dan jarak titik bor satu dengan lainnya. Pinset dan suntikan sesuai ukuran bor. Alkohol $70 \%$ untuk sterilkan alat dan lubang hasil bor kayu. Masker, gunting serta kapas. Sarung tangan karet dan Inokulan Gaharu. Cara Inokulasi menggunakan inokulan serbuk: menggunakan masker dan sarung tangan dari karet untuk keamanan kemudian menyemprotan semua peralatan dengan menggunakan alkohol 70\%, membuat lubang bor pada batang sedalam $1 / 3$ batang secara horizontal (gunakan mata bor $6 \mathrm{~mm}$ atau $8 \mathrm{~mm}$ ) dengan jarak seperti dijelaskan di atas dan masukkan inokulan serbuk ke dalam lubang bor menggunakan bantuan plat alumunium dan stik pendorong secara aseptik. Sedangkan cara inokulasi menggunakan inokulan cair dilakukan dengan cara membuat lubang bor pada batang (lubang bor pertama 50-70 cm dari leher batang) sedalam $1 / 3$ hingga $1 / 2$ diameter batang dengan kemiringan $45^{\circ}$ kemudian sedot cairan inokulan cair sebanyak $70 \mathrm{~mL}$ kemudian tusukkan alat suntik pada lubang bor. Sebelum dimasukkan ke dalam lobang inokulan harus diblender terlebih dahulu agar dalam proses penyuntikan tidak macet. Inokulan dimasukkan dengan pinset kedalam suntikan yang ujungnya sudah dipotong, kemudian inokulan dimasukkan kedalam lubang sampai penuh. Syarat inokulasi untuk pohon penghasil gaharu yaitu pohon harus sehat, memiliki diameter $>15 \mathrm{~cm}$, berbunga atau berbuah. Penyuntikan dilakukan pada saat tidak hujan dengan jumlah inokulan : 0,5-1 ml untuk setiap lobang. ${ }^{5}$

5 Santoso E. 1996. Pembentukan Gaharu dengan Cara Induksi. Makalah dalam Diskusi Hasil Penelitian dalam Menunjang Pemanfaatan Hutan yang Lestari. Bogor : Badan Litbang Kehutanan Konservasi, 11-12 Maret 1996 
a

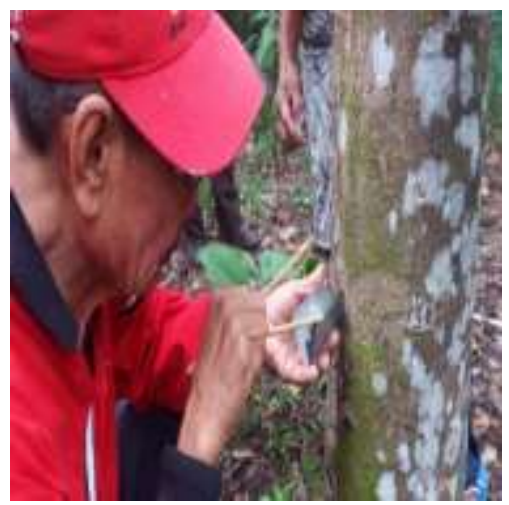

$\mathrm{b}$

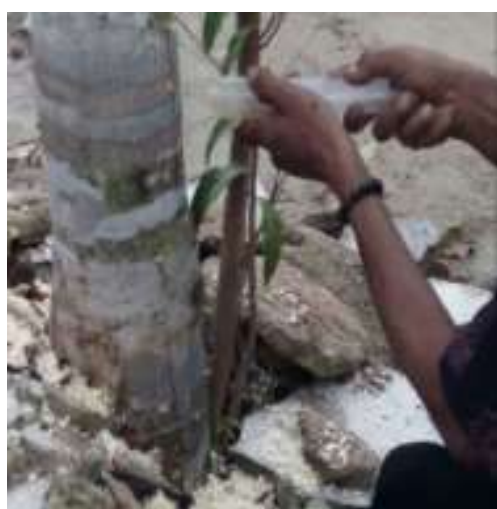

Gambar 4. Teknik inokulasi cendawan ke pohon gaharu, a. media padat, b. media cair

\section{Pelatihan pembuatan tasbih, analisis keuntungan dan pembukuan}

Target luaran kegiatan pelatihan diversifikasi produk yaitu meningkatkan keterampilan dan pendapatan masyarakat melalui peningkatan nilai tambah produk gaharu selain kayu sedangkan untuk pelatihan analisi keuntungan dna pembukuan yaitu masyarakat mengetahui besarnya keuntungan yang akan diperoleh dari produk olahan selain kayu dan tahu bagaimana membuat pembukuannya dan memotivasi masyarakat untuk mengembangkan produk olahan gaharu selain kayu sehingga meningkatkan kesejahteraan masyarakat. Alat yang digunakan yaitu mesin bor duduk $13 \mathrm{~mm}$, mata bor berbagai ukuran tergantung besar kecilnya bulatan tasbih yang akan dibuat, Bahan yang diperlukan amplas, batang/kayu gaharu, dan daun pisang. Pembuatan tasbih/gelang dilakukan dengan cara: Pertama, kayu gaharu dipotong kecil-kecil sesuai ukuran yang akan dibentuk. Setelah itu, potongan kayu akan diproses menjadi butiran tasbih dengan mengunakan mesin gerinda. Berikutnya dilakukan proses penghalusan butiran tasbih dengan menggunakan amplas.

Pada kegiatan ini juga dijelaskan keuntungan menggunakan inokulan buatan. Pada kegiatan ini juga dijelaskan cara membuat pembukuan sederhana dengan mencatat segala pemasukan dan pengeluaran kemudian dihitung keuntungannya. Analisis keuntungan ini berguna untuk mengetahui besarnya keuntungan yang akan diperoleh petani dari produk olahan selain kayu. Keuntungan dapat diperoleh dari selisih penerimaan dengan biaya yang dikeluarkan.

Volume 2, Number 1, Mei 2018| 48 Pendampingan Petani Gaharu melalui Program Diversifikasi Produk Gaharu sebagai Usaha Peningkatan Pendapatan Petani Gaharu di Kabupaten Bangka Tengah 


\section{ENGAGEMENT}

Jurnal Pengabdian Kepada Masyarakat

ISSN: 2579-8375 (Print)

ISSN: 2579-8391 (Online)
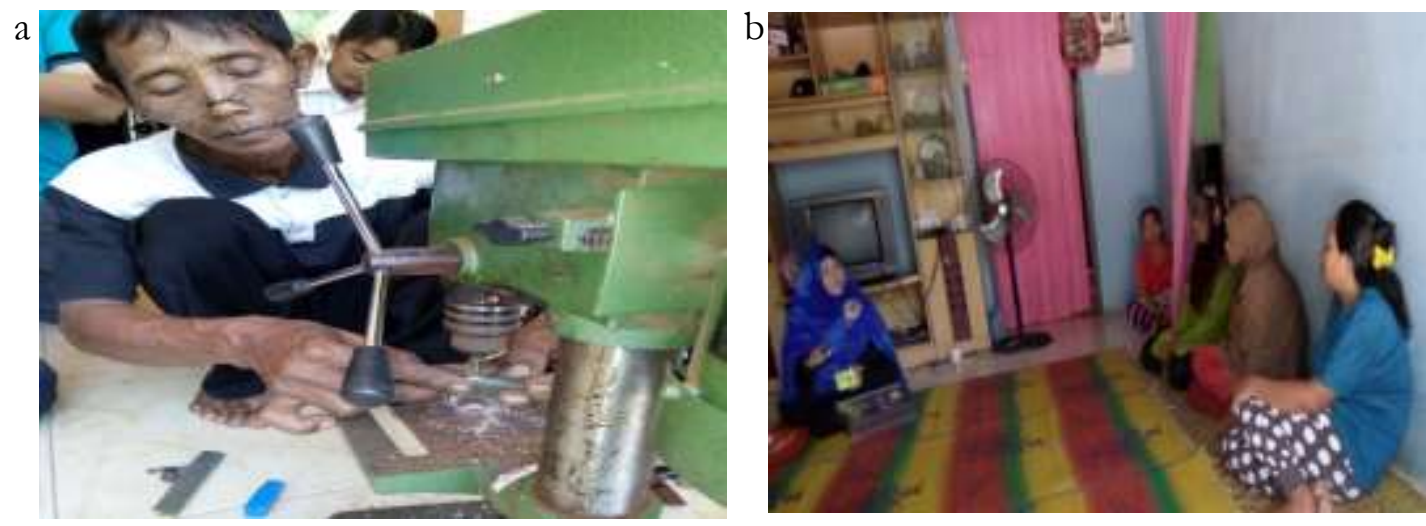

Gambar 5.a. pembuatan tasbih, b. pelatihan analisis keuntungan dan pembukuan sederhana

Contoh pembukuan sederhana

Bulan :.............................

\begin{tabular}{|l|c|c|c|c|}
\hline \multirow{2}{*}{ Tanggal } & \multicolumn{2}{c|}{ Pemasukan } & \multicolumn{2}{c|}{ Pengeluaran } \\
\cline { 2 - 5 } & Keterangan & Jumlah & Keterangan & Jumlah \\
\hline & & & & \\
\hline & & & & \\
\hline Total & & & & \\
\hline Saldo & & & & \\
\hline
\end{tabular}

\section{Kesimpulan}

Setelah kegiatan ini, petani paham pentingnya konservasi gaharu dan budidaya gaharu. Petani juga dapat membuat inokulan sendiri, mampu melakukan inokulasi cendawan ke batang pohon gaharu. Petani menyadari pentingnya inokulan dan teknik inokulasi yang benar. Dari kegiatan ini tidak hanya petani saja yang dilibatkan namun istri petani juga dapat berpartisipasi terutama dalam pembuatan inokulan dan pembuatan tasbih. Kelompok Tani terutama Poktan Pasir Air Maju Lampur masih perlu dibina lebih lanjut karena keinginan kuat dari beberapa anggota tani untuk mengembangkan gaharu namun masih kurang pembinaan sehingga perlu dilakukan kegiatan lanjutan melalui kerjasama antara Perguruan Tinggi dan Pemerintah Daerah.

Volume 2, Number 1, Mei 2018| 49

Pendampingan Petani Gaharu melalui Program Diversifikasi Produk Gaharu sebagai Usaha Peningkatan Pendapatan Petani Gaharu di Kabupaten Bangka Tengah

Henny Helmi, Eni Karsiningsih 


\section{Daftar Referensi}

Barden A, Anak NA, Mulliken T, Song M. Heart of the Matter. Agarwood Use andTrade and CITIES Implementation for Aquilaria malaccensis. Cambridge: Traffic Int, 2000

Putri A, Rahayu G, Juliarni. 2007. "Induksi Pembentukan Wangi dan Senyawa Terpenoid pada Pohon Gaharu denganAcremonium sp. dan Metil Jasmonat”. Jurnal Pertanian dan Lingkungan. Volume 2 No. 1. (2007):23-28.

Michiho,I. "Induction of sesquiterpenoid Production by Methyl Jasmonate in Aquilaria sinensis Cell Suspension Culture”. Essential oil Research (2005) diakses 20 April 2014. http://www.findarticle.com

Panjaitan S, Eko HK, Tri W, dan Edy S. Prospek dan Teknik Budidaya Tumbuhan gaharu (Aquilaria malaccensis) di Kalimantan. Banjar Baru.: Balai Penelitian Kehutanan BPDAS Barito, 2009

Santoso E. 1996. Pembentukan Gaharu dengan Cara Induksi. Makalah dalam Diskusi Hasil Penelitian dalam Menunjang Pemanfaatan Hutan yang Lestari. Bogor : Badan Litbang Kehutanan Konservasi, 11-12 Maret 1996. 